\title{
Analysis of the Unit Performance Degradation for Top Heater Out-of-service Operation Condition
}

\author{
Haisheng Yang, Shuping Chang, Ruitao Wu \\ Thermal Technology Depart, Hebei Electric Power Research Institute, Shijiazhuang, Hebei PRC \\ Email: haisheng.yang@gmail.com, hbdyycsp@163.com, hbdyywrt@163.com \\ Received September, 2012
}

\begin{abstract}
To analyze the unit performance degradation for top heater out-of-service operation condition, two calculation methods were introduced, that was the model based calculation method and the simplified variable operation condition analysis method. A 600MW sub-critical steam turbine unit with air cooled condenser was analyzed using the two introduced methods. It is shown that calculation data got can reflect the redistribution effect on steam flows of the turbine extractions and turbine internals due to the top heater out-of-service, and similar and close calculation results were got from the two methods, and both results were lower than result calculated using the commonly used equivalent enthalpy drop method.
\end{abstract}

Keywords: Top Heater; Out-of-service; Performance Degradation; Analysis Method

\section{Introduction}

Presently the Equivalent Enthalpy Drop Method is commonly used in the performance quantitative analysis of the steam turbine units. For the top heater out-of-service operation condition for the steam turbine unit, the quantitative analysis equation in [1] is widely used to determine the effect on unit performance.

In Ref [2], the impact of top heater out-of-service condition was analyzed under the consumption that the top heater out-of-service operation was a small disturbance to the normal operation conditions. In Ref [3], the impact of top heater out-of-service condition was calculated by the Variable Operation Condition Analysis Method and Matrix Method (based on the small disturbance consumption), and it was concluded that there was minor difference between the two calculated results.

Theoretically, the Equivalent Enthalpy Drop Method is based on the certain assumption, that is the parameters of the live steam, reheat steam, the turbine end, and the extractions are kept constant, or the change of the turbine expansion line is not considered. The mentioned assumption is the precondition for establishing the concept and equations of the Equivalent Enthalpy Drop Analysis Method.

Under practical operation conditions, when the top heater is out-of-service, there is a dramatic change of the unit operation condition and turbine internal flow and parameters. Thus, the Equivalent Enthalpy Drop Method is not very applicable for analysis of this operation con- dition change.

\section{Two Calculation Methods for Analyzing the Impact of Top Heater Out-of-Service Condition}

To analyze the unit performance degradation for top heater out-of-service operation condition, two calculation methods are introduced, that is the Model-based Calculation Method and the Simplified Variable Operation Condition Analysis Method.

\subsection{The Model-based Calculation Method for Thermal System}

During normal operation, the operation parameters and the equipment performance are inter-related and coupled. The model-based calculation method can reflect the coupling relationship between the equipment performance and the operation conditions, thus provide a clear picture of the influence between the equipment and boundary conditions, especially for operation conditions with large scale change of operation parameters, equipment performance and operation loading.

Model-based calculation software such as GateCycle, can provide analysis for all various changes of the operation parameters and equipment performance degradation. This method can consider the change factors and its related effect on the thermal system, thus providing an complete variable Operation Condition Analysis for the system. 
Advantages of the Model-based Calculation Method.

Some advantages of using the model based analysis or calculation method are listed below:

a) Interaction of varying operating conditions can be modeled: Models can allow wide variations in operation parameters from the rated conditions.

b) Model-based calculation can compute impacts of parameters for which no curves are available.

c) Model-based calculation can handle various equipment and thermal systems, such as fossil-fired generation unit, combined cycle generation unit, cogeneration unit, and advanced gas turbine generation unit.

d) Model-based calculation can share information between different operation conditions, such as design and off-design conditions.

The typical process of model-based performance analysis includes the following steps:

a) Model building: Build a model of the equipment or system being monitored.

b) Model testing: Test the model versus manufacture guarantee data or measured data over a wide range of operation conditions. Correct the model where necessary.

c) Data input: Input the measured equipment operation conditions into the model.

d) Run the model: obtain the expected equipment or system performance model output.

e) Evaluate degradation: comparing the expected performance from the model calculation to the measured performance.

\subsection{Simplified Variable Operation Condition Analysis Method for Thermal System}

The Simplified Variable Operation Condition Analysis Method handles the steam turbine into stage groups based on turbine extractions. The turbine extraction parameters under variable operation condition can be determined if the steam turbine expansion process is determined. Thus the thermal performance of the system can be calculated.

First, based on the operation data of the baseline operation condition, the flow coefficient for turbine extractions can be calculated as:

$$
C=\frac{w}{\sqrt{p / v}}
$$

where, $C$ is the flow coefficient; $W$ is the steam flow upstream of the turbine extractions; $p$ is the pressure upstream of the turbine extractions; $v$ is the steam specific volume upstream of the turbine extractions. If the extraction temperature change is relatively minor during the operation condition change, the flow coefficient can be simplified as the ratio of the steam flow to the pressure.

Secondly, the extraction parameters under variable operation condition can be calculated based on the assumed turbine expansion line (related to turbine efficiency), the changed steam flow, and the determined flow coefficient of the extractions. The thermal performance of the system can be calculated.

Based on the new steam flow distribution data, the turbine extraction parameters can be corrected until the bias between the two iterations is within a set limit.

Finally, based on the exhaust steam flow result from the previous step, and the exhaust loss curve provided by the manufacture, the exhaust loss of the turbine last stage and the turbine used energy of end point $\left(h_{\text {UEEP }}\right)$ can be calculated, and the unit power output can be determined by energy balance calculation.

The above mentioned calculation process is similar to the correction process of the calculation example included in the Appendix of the ASME PTC 6 standard. The steam turbine expansion line can be determined based on the baseline operation data. The turbine casing efficiency under variable operation condition is set the same as the baseline operation condition.

\section{Calculation Example of Analyzing the Impact of Top Heater Out-of-Service Condition}

For one example generation unit, the 660MW steam turbine is a sub-critical, single-shaft, four-casing four-exhaust condensing steam turbine with air-cooled condensers. Steam turbine is designed with seven extractions, which supplies steam to three HP heaters, one deaerator, and three LP heaters. The top HP heater heating steam is supplied from the HP turbine extraction, and second HP heater heating steam is supplied from the HP turbine exhaust, and the third HP heater heating steam is supplied from the IP turbine extraction.

The main design data of the steam turbine is summarized in Table 1.

Table 1. Main design data of the $600 \mathrm{MW}$ steam turbine.

\begin{tabular}{lcc}
\hline \multicolumn{1}{c}{ Item } & Unit & Design Data \\
\hline Generator Output & $\mathrm{MW}$ & 600 \\
Main Steam Flow Rate & $\mathrm{t} / \mathrm{h}$ & 1843.63 \\
Hot Reheat Flow Rate & $\mathrm{t} / \mathrm{h}$ & 1584.03 \\
Main Steam Pressure & $\mathrm{MPa}$ & 16.70 \\
Hot Reheat Pressure & $\mathrm{MPa}$ & 3.435 \\
Main Steam/ Hot Reheat Steam Temperature & ${ }^{\circ} \mathrm{C}$ & $538 / 538$ \\
Heat Rate & $\mathrm{kJ} / \mathrm{kWh}$ & 8080.4 \\
Final Feedwater Temperature & ${ }^{\circ} \mathrm{C}$ & 274.96 \\
Makeup Water Rate & ${ }^{\circ} \%$ & 0 \\
Turbine Back Pressure & $\mathrm{kPa}$ & 16 \\
\hline
\end{tabular}


Table 2. Calculation result by the model-based calculation method.

\begin{tabular}{|c|c|c|c|c|}
\hline Item & Unit & $\begin{array}{l}\text { Baseline } \\
\text { Condition }\end{array}$ & $\begin{array}{l}\text { Top Heater Out-of-Service } \\
\text { (Fixed Pressure Mode) }\end{array}$ & $\begin{array}{l}\text { Top Heater Out-of-Service } \\
\text { (Sliding Pressure Mode) }\end{array}$ \\
\hline Generator Output & $\mathrm{kW}$ & 599631 & 626266 & 624117 \\
\hline Total Heating Energy & $\mathrm{kJ} / \mathrm{sec}$ & -1345921 & -1414107 & -1409912 \\
\hline Unit Heat Rate & $\mathrm{kJ} / \mathrm{kW} \cdot \mathrm{h}$ & 8080.56 & 8128.8 & 8132.4 \\
\hline Relative Change of the Generator Output & $\%$ & & 4.4418 & 4.0835 \\
\hline Relative Change of the Unit Heat Rate & $\%$ & & 0.5970 & 0.6415 \\
\hline
\end{tabular}

Table 3. Calculation result by the simplified variable operation condition analysis method.

\begin{tabular}{|c|c|c|c|c|}
\hline Item & Unit & $\begin{array}{l}\text { Baseline } \\
\text { Condition }\end{array}$ & $\begin{array}{l}\text { Top Heater Out-of-Service } \\
\text { (Fixed Pressure Mode) }\end{array}$ & $\begin{array}{l}\text { Top Heater Out-of-Service } \\
\text { (Sliding Pressure Mode) }\end{array}$ \\
\hline Mail Steam Flow & $\mathrm{t} / \mathrm{h}$ & 1843.628 & 1843.628 & 1837.440 \\
\hline Main Steam Pressure & $\mathrm{MPa}$ & 16.700 & 16.700 & 16.700 \\
\hline Main Steam Temperature & ${ }^{\circ} \mathrm{C}$ & 538.000 & 538.000 & 538.000 \\
\hline Extraction \#1 Pressure & $\mathrm{MPa}$ & 5.977 & 6.412 & 6.391 \\
\hline Extraction \#1 Temperature & ${ }^{\circ} \mathrm{C}$ & 382.163 & 391.656 & 391.495 \\
\hline Top HP Heater Outlet Temperature & ${ }^{\circ} \mathrm{C}$ & 274.956 & 249.862 & 249.673 \\
\hline Top HP Heater Drain Temperature & ${ }^{\circ} \mathrm{C}$ & 251.414 & 255.465 & 255.272 \\
\hline Extraction \#1 Flow & $\mathrm{t} / \mathrm{h}$ & 126.151 & -0.013 & 0.002 \\
\hline Extraction \#2 Pressure & $\mathrm{MPa}$ & 3.817 & 4.090 & 4.076 \\
\hline Extraction \#2 Temperature & ${ }^{\circ} \mathrm{C}$ & 322.665 & 331.091 & 330.960 \\
\hline \#2 HP Heater Outlet Temperature & ${ }^{\circ} \mathrm{C}$ & 245.814 & 249.865 & 249.672 \\
\hline \#2 HP Heater Drain Temperature & ${ }^{\circ} \mathrm{C}$ & 217.253 & 220.679 & 220.515 \\
\hline Extraction \#2 Flow & $\mathrm{t} / \mathrm{h}$ & 126.894 & 139.889 & 139.214 \\
\hline HP Turbine Exhaust Pressure & $\mathrm{MPa}$ & 3.817 & 4.090 & 4.076 \\
\hline HP Turbine Exhaust Temperature & ${ }^{\circ} \mathrm{C}$ & 322.665 & 331.091 & 330.960 \\
\hline HP Turbine Exhaust Flow & $\mathrm{t} / \mathrm{h}$ & 1584.031 & 1697.201 & 1691.671 \\
\hline HP Turbine Efficiency & & 0.884 & 0.885 & 0.883 \\
\hline Hot Reheat Steam Pressure & $\mathrm{MPa}$ & 3.435 & 3.680 & 3.668 \\
\hline Hot Reheat Steam Temperature & ${ }^{\circ} \mathrm{C}$ & 538.000 & 538.000 & 538.000 \\
\hline Extraction \#3 Pressure & $\mathrm{MPa}$ & 2.032 & 2.174 & 2.167 \\
\hline Extraction \#3 Temperature & ${ }^{\circ} \mathrm{C}$ & 456.393 & 456.050 & 456.065 \\
\hline \#3 HP Heater Inlet Temperature & ${ }^{\circ} \mathrm{C}$ & 184.112 & 186.991 & 186.850 \\
\hline \#3 HP Heater Outlet Temperature & ${ }^{\circ} \mathrm{C}$ & 211.653 & 215.079 & 214.915 \\
\hline Extraction \#3 Flow & $\mathrm{t} / \mathrm{h}$ & 74.763 & 82.591 & 82.219 \\
\hline \#3 HP Heater Drain Flow & $\mathrm{t} / \mathrm{h}$ & 327.808 & 222.466 & 221.436 \\
\hline Condensate Flow & $\mathrm{t} / \mathrm{h}$ & 1427.319 & 1522.438 & 1517.687 \\
\hline IP Turbine Exhaust Pressure & $\mathrm{MPa}$ & 0.455 & 0.485 & 0.483 \\
\hline IP Turbine Exhaust Temperature & ${ }^{\circ} \mathrm{C}$ & 257.070 & 256.229 & 256.261 \\
\hline IP Turbine Efficiency & & 0.940 & 0.940 & 0.940 \\
\hline LP Turbine Exhaust Flow & $\mathrm{t} / \mathrm{h}$ & 1220.466 & 1295.409 & 1291.676 \\
\hline LP Turbine Exhaust Pressure & $\mathrm{kPa}$ & 16.000 & 16.000 & 16.000 \\
\hline LP Turbine Exhaust Enthalpy (UEEP) & $\mathrm{kJ} / \mathrm{kg}$ & 2444.659 & 2432.940 & 2433.490 \\
\hline HP Turbine Work & $\mathrm{kW}$ & 185685.64 & 181960.22 & 181340.88 \\
\hline IP Turbine Work & $\mathrm{kW}$ & 233858.72 & 250197.36 & 249400.39 \\
\hline LP Turbine Work & $\mathrm{kW}$ & 190266.08 & 205653.72 & 204881.90 \\
\hline Relative Change of HP Turbine Work & $\%$ & & -2.0063 & -2.3398 \\
\hline Relative Change of IP Turbine Work & $\%$ & & 6.9865 & 6.6458 \\
\hline Relative Change of LP Turbine Work & $\%$ & & 8.0874 & 7.6818 \\
\hline Generator Output & $\mathrm{kW}$ & 600104.72 & 627769.56 & 625607.70 \\
\hline Unit Heat Rate & $\mathrm{kJ} / \mathrm{kWh}$ & 8080.402 & 8125.045 & 8128.772 \\
\hline Relative Change of Generator Output & $\%$ & & 4.6100 & 4.2498 \\
\hline Relative Change of Unit Heat Rate & $\%$ & & 0.5525 & 0.5986 \\
\hline
\end{tabular}


Table 4. Calculation result by the equivalent enthalpy Drop method.

\begin{tabular}{|c|c|c|c|}
\hline Item & Symbols & Unit & Result \\
\hline $\begin{array}{l}\text { Increasing of the Equavalent Enthalpy } \\
\text { Drop }\end{array}$ & $\triangle \mathrm{H}$ & $\mathrm{kJ} / \mathrm{kg}$ & 66.97 \\
\hline Increasing of the Total Heat Absorbed & $\triangle \mathrm{Q}$ & $\mathrm{kJ} / \mathrm{kg}$ & 171.57 \\
\hline $\begin{array}{l}\text { Relative Increasing of the Generator } \\
\text { Output }\end{array}$ & $\triangle \mathrm{P}$ & $\%$ & 5.639 \\
\hline $\begin{array}{l}\text { Relative Decreasing of the Cycle } \\
\text { Efficiency (Heat Rate) }\end{array}$ & $\delta \eta$ & $\%$ & 0.838 \\
\hline
\end{tabular}

For the top HP heater out-of-service operation condition, two calculation methods are adopted, and the calculation results are described below.

1) Calculation Result by the Model-based Calculation Method

The calculation result by the Model-based Calculation Method is summarized in Table 2.

2) Calculation Result by the Simplified Variable Operation Condition Analysis Method

The calculation result by the Simplified Variable Operation Condition Analysis Method is summarized in Table 3.

3) Comparison and Analysis of the Calculation Results

It is shown that calculation results from the proposed two methods are very close. Because in both methods, the redistribution effect on steam flows of the turbine extractions and turbine internals due to the top heater out-of-service is considered, and there is no significant difference between the two methods in essence.

For evaluating and crosscheck of the calculated results, the calculated result using the commonly used Equivalent Enthalpy Drop Method is also shown in Table 4.

It can be shown clearly that both results by the proposed methods are lower than result calculated using the commonly used equivalent enthalpy drop method.

In summary, the calculated results calculated by the proposed methods have higher credibility than the result calculated by the commonly used method. The commonly used Equivalent Enthalpy Drop Method is not recommended for analyzing the significant operation condition change situations, because the dramatic change of the operation conditions under these situations can't meet the assumptions and preconditions of this method, which is the basis for deducing the concept and equations of this method.

\section{Conclusions}

To analyze the unit performance degradation for top heater out-of-service operation condition, two calculation methods are introduced, that is the model based calculation method and the simplified variable operation condition analysis method.

A $600 \mathrm{MW}$ sub-critical steam turbine unit with air cooled condenser is analyzed using the two introduced methods. It is shown that calculation data got can reflect the redistribution effect on steam flows of the turbine extractions and turbine internals due to the top heater out-of-service, and similar and close calculation results are calculated from the two methods, and both results are lower than result calculated using the commonly used equivalent enthalpy drop method.

\section{REFERENCES}

[1] W. C. Lin, "Energy-saving Theory of Fossil Fired Power Plant Thermal Systems," Xi'an, China: Xi'an Jiaotong University Press, 1994.

[2] S. L. Yan, "Research on the Calculation Model of the Unit Performance Degradation for Top Heater Out-of-service Operation Condition," Turbine Technology, Harbin China, Vol. 49, No. 6, 2007, pp. 420-422.

[3] C. F. Zhang, "Quantitative Study on the Limitation of Small Disturbance Theory based on the Top Heater Out-of-service Operation Condition," Turbine Technology, Harbin China, Vol. 50, No. 1, 2008, pp. 34-36. 